\title{
Menuju Manufaktur Berkelanjutan di Indonesia: Tantangan dan Kesempatan
}

\author{
Jessica Hanafi ${ }^{*}$
}

\begin{abstract}
Global competitivenes have stimulated Indonesia to improve its economy. Therefore, the Indonesian government aims to improve industry competitiveness through sustainable development and increasing added value. This is stated in the Masterplan for Acceleration and Expansion of Indonesia's Economic Development. One of the method to answer the globalisation challenge is by implementing sustainable manufacturing. Sustainable manufacturing begins with lean manufacturing, cleaner production and life cycle assessment by considering health and safety of employee, customer, and the society. There are challenges in implementing sustainable manufacturing. There are also varied indicators for organisation's sustainability. However, all of them are based on the triple bottom line, which are economy, social and environmental. This paper will discuss how sustainable manufacturing is viewed from three perspectives, based on industry, government and academics, especially in Indonesia.
\end{abstract}

Keywords: Sustainable manufacturing, life cycle assessment, sustainability indicator, MP3EI.

\section{Pendahuluan}

Perkembangan dunia saat ini diikuti oleh peningkatan populasi, peningkatan konsumsi, industrialisasi, semakin terkikisnya sumber daya alam serta polusi dan perubahan iklim. Keadaan ini perlu diingat bahwa pembangunan dan perkembangan yang terjadi jangan hanya menciptakan kekayaan dan kesuksesan namun juga harus dapat diturunkan ke anak cucu kita. Inilah yang menjadi motivasi munculnya pembangunan berkelanjutan. Pembangunan berkelanjutan mencetuskan manajemen berkelanjutan di segala aspek, salah satunya adalah manufaktur berkelanjutan.

Pada tahun 2010 pemerintah Indonesia menetapkan Masterplan Percepatan dan Perluasan Pembangunan Ekonomi Indonesia yang lebih dikenal dengan sebutan MP3EI. Di dalam MP3EI dirumuskan rencana jangka panjang pemerintah untuk meningkatkan produk domestik bruto, dari US $\$ 700$ miliar pada tahun 2010 menjadi US $\$ 4-4.5$ triliun pada tahun 2025 dan US\$ $15-17,5$ triliun pada tahun 2045. Tujuan dari MP3EI adalah untuk meningkatkan nilai tambah dan memperluas rantai nilai proses produksi serta jaringan distribusi, selain itu juga untuk mendorong efisiensi produksi dan pemasaran serta integrasi pasar domestik dalam rangka penguatan daya saing dan daya tahan perekonomian nasional. MP3EI juga berupaya untuk men-

${ }^{1}$ Fakultas Sains dan Teknologi, Jurusan Teknik Industri, Universitas Pelita Harapan, J. M.H Thamrin Boulevard, Lippo Karawaci, Tangerang, Banten 15811. Indonesia.

Email: jessica.hanafi@uph.edu

* Penulis korespondensi dorong penguatan sistem inovasi nasional di sisi produksi, proses, maupun pemasaran untuk penguatan daya saing global yang berkelanjutan menuju innovation-driven-economy. Daya saing global yang berkelanjutan dan visi dalam MPE3EI inilah yang menjadi salah satu pendorong upaya menuju manufaktur berkelanjutan di Indonesia. Diharapkan Indonesia dapat turut serta bersaing secara global namun tetap dapat menjaga keberlangsungan dari sumber daya dan produksinya.

Menurut US Environmental Protection Agency (US EPA), manufaktur berkelanjutan atau sustainable manufacturing adalah penciptaan produk manufaktur melalui proses ekonomis yang mengurangi dampak lingkungan negatif sambil turut menjaga kelestarian energi dan sumber daya alam. Manufaktur berkelanjutan juga menjaga keselamatan karyawan, masyarakat dan konsumen. US EPA [1] juga menyebut manufaktur berkelanjutan sebagai desain berkelanjutan atau desain hijau. Konsep manufaktur berkelanjutan di dunia sudah dimulai sejak sekitar tahun 2000 (O’ Brien [2], Westkämper [3], Rashid [4], Bocken et al. [5]). Landasan dari manufaktur berkelanjutan ini adalah konsep daur hidup, dimana suatu produk atau proses tidak lagi hanya dilihat dari proses manufakturnya saja namun juga dari keseluruhan daur hidupnya, mulai dari pengadaan bahan mental, produk jadi, sampai tahap penggunaan (usage stage), dan akhir hidup dari produk (end-of-life).

Pada makalah ini akan dibahas isu manufaktur berkelanjutan dilihat dari ketiga perspektif, yaitu sisi industri, pemerintah dan akademia, khususnya di Indonesia. Bagaimana keterlibatan ketiga pemangku kepentingan mempengaruhi manufaktur berkelan- 
jutan dan tantangan serta kesempatan yang ada. Pertama-tama akan dibahas mengenai apa yang dimaksud dengan manufaktur berkelanjutan dan prinsipnya. Indikator apa yang digunakan untuk mengukur keberlanjutan di industri. Selanjutnya akan dilihat perspektif pemerintah dan akademia mengenai manufaktur berkelanjutan. Terakhir, kesimpulan mengenai tantangan dan kesempatan akan dipaparkan.

\section{Metode Penelitian}

Makalah ini berisi paparan kajian mengenai isu manufaktur berkelanjutan di Indonesia. Kajian ini berdasarkan gabungan hasil kajian literatur, laporan industri dan studi kasus pada industri. Terdapat 31 literatur yang dikaji secara menyeluruh pada penelitian ini. Laporan industri yang dijadikan sebagai bahan acuan untuk mengetahui perilaku keberlanjutan perusahaan adalah laporan keberlanjutan (sustainability report). Tiga puluh lima laporan keberlanjutan berasal dari berbagai sektor yang dilaporkan pada kurun waktu 2010-2014 dianalisa. Perusahaan-perusahaan yang mempunyai laporan keberlanjutan umumnya merupakan perusahaan terbuka yang terdaftar pada pasar modal. Sementara itu untuk mengetahui keadaan keberlanjutan industri kecil dan menengah dilakukan studi kasus pada 15 industri manufaktur yang berlokasi di sekitar Jabodetabek. Peraturan perundang-undangan dan peran serta pemerintah juga dipaparkan yang informasinya dikumpulkan dari laman-laman kementerian terkait. Hasil analisa dibahas pada bagian berikut berdasarkan ketiga pemangku kepentingan, yaitu dari sisi industri, pemerintah dan akademik.

\section{Hasil dan Pembahasan}

\section{Manufaktur Berkelanjutan}

Pada tahun 1992 dilaksanakan seminar oleh PBB, United Nation Conference on Environment and Development, di Rio de Janeiro yang dikenal dengan nama Rio Declaration. Pada konferensi ini ditekankan kewajiban produsen, konsumen dan pemerintah dalam mensukseskan manufaktur berkelanjutan. Beberapa strateginya adalah penggunaaan atau pemilihan proses produksi yang lebih efisien secara energi dan sumber daya alam, strategi pencegahan (preventive strategies), teknologi produksi bersih untuk seluruh daur hidup produk, serta minimisasi dan pencegahan limbah (O’Brien [2]).

Penerapan manufaktur berkelanjutan dalam industri manapun, termasuk industri di Indonesia, tidak hanya memerlukan perencanaan sistem produksi yang berlandaskan ketiga pilar berkelanjutan

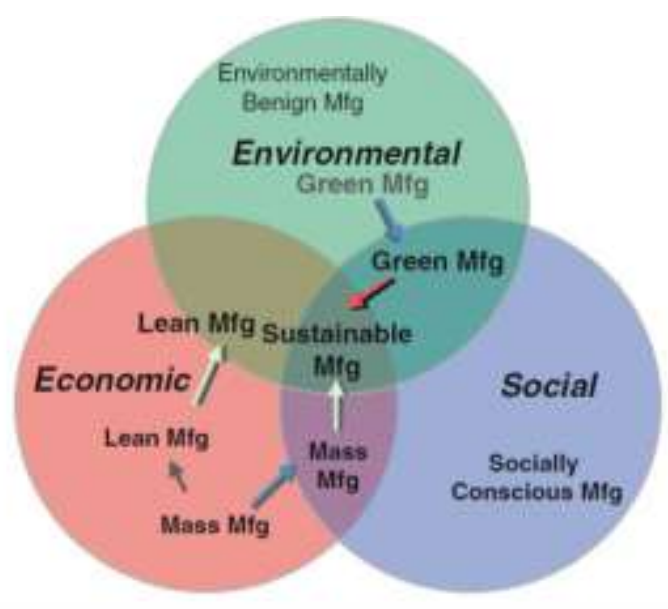

Gambar 1. Manufaktur berkelanjutan (Dornfeld et al. [15])

(ekonomi, sosial, lingkungan), melainkan juga sebuah metode penerapan yang holistik untuk mendukung penerapan konsep perbaikan berkesinambungan (continuous improvement). Konsep perbaikan berkesinambungan menjadi penting untuk dimasukkan dalam kerangka penerapan manufaktur berkelanjutan karena perusahaan akan dapat meningkatkan standarnya secara terus menerus. Perubahan untuk dapat menuju industri manufaktur yang berkelanjutan tidak dapat dilakukan secara sekejap. Perubahan sedikit demi sedikit yang dilakukan secara terus menerus akan lebih mudah diterapkan.

Pengukuran kinerja keberlanjutan selalu berdasarkan pada the triple bottom line, yang fokus pada lingkungan, ekonomi, dan sosial (Gambar 1). Sebuah perusahaan akan dikatakan memiliki sistem manufaktur yang berkelanjutan jika perusahaan tersebut sudah dapat mencapai taraf keberlanjutan di ketiga aspek tersebut. Namun perusahaan tidak dapat memisahkan peningkatan keberlanjutan di masing-masing aspek karena aspek-aspek tersebut akan terus berkaitan. Dalam mendorong keberlanjutan di bidang ekonomi dan lingkungan, perusahaan perlu untuk menerapkan sistem manufaktur yang ramping (lean manufacturing). Dalam mendorong keberlanjutan di bidang ekonomi dan sosial, yang perlu diterapkan perusahaan adalah manufaktur massal (mass manufacturing). Untuk meningkatkan keberlanjutan di bidang lingkungan dan sosial, perusahaan membutuhkan penerapan manufaktur hijau (green manufacturing). Oleh karena itu, dapat disimpulkan bahwa dalam mencapai sebuah sistem manufaktur yang berkelanjutan, perusahaan harus menerapkan sistem manufaktur yang ramping, massal dan hijau (Reich-Weiser et al. [6])

Berbagai upaya dilakukan untuk mencapai keberlanjutan ini. Strategi manufaktur seperti lean manufacturing dan cleaner production juga berperan 


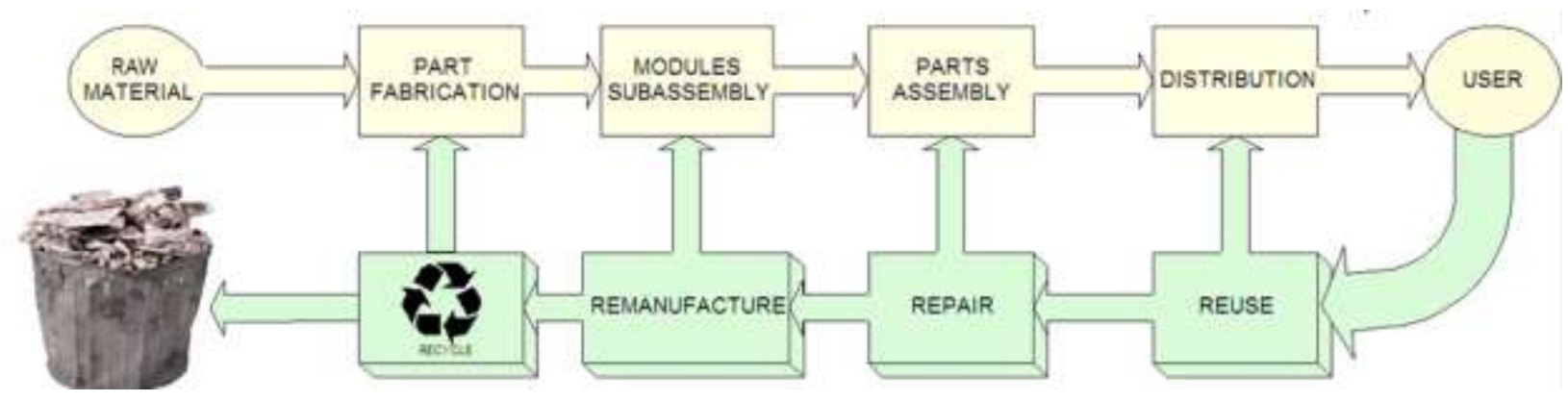

Gambar 2 Konsep daur hidup produk (Hanafi et al. [22])

dalam mengurangi dampak negatif lingkungan dari proses produksi (Huang et al. [7], Büyükbay et al. [8], Almeida et al. [9], van Hoof dan Lyon [10], Niinimäki dan Hassi [11], Khalili et al. [12], Grutter dan Egler [13], Narayanaswamy dan Stone [14]). Huang et al. [7] mengidentifikasi adanya peningkatan konservasi energi, pengurangan konsumsi bahan mentah dan air, peningkatan utilisasi secara keseluruhan dan pengurangan emisi polutan. Huang et al. juga menegaskan bahwa untuk mencapai keberlanjutan produksi bersih merupakan proses yang terus menerus yang harus dilakukan. Namun seperti van Hoof dan Lyon [10], Huang et al. [7] juga menekankan bahwa walaupun produksi bersih banyak berhasil dilakukan di perusahaan besar, penerapan di usaha kecil dan menengah ditemukan banyak hambatan.

Seperti disebutkan sebelumnya, dalam manufaktur berkelanjutan terdapat tiga aspek utama yang harus diperhatikan, yaitu ekonomi, sosial dan lingkungan serta sambil memperhatikan keselamatan karyawan, konsumen dan masyarakat, maka suatu produk dan proses tidak hanya bisa dilihat sampai produk tersebut selesai diproduksi, namun harus melihat secara keseluruhan daur hidup dari produk tersebut (life cycle approach) (Gambar 2). Life Cycle Assessment (LCA) adalah metode yang dapat digunakan untuk mengetahui dampak terhadap lingkungan, kesehatan manusia dan sumber daya alam. Melalui LCA, setiap proses dalam setiap tahapan hidup suatu produk diukur, diinventarisasi dan diinterpretasi sehingga dapat diketahui dampaknya (Guinée [16], ISO[17]). Konsep daur hidup ini kemudian berevolusi menjadi life cycle costing dan social life cycle assessment untuk mengevaluasi dampak suatu proses dan produk terhadap ekonomi dan dampak sosial, secara berurutan, yang dikembangkan oleh United Nation Environmental Program (UNEP) dalam Life Cycle Initiatives [18], UNEP-SETAC [19].

Berdasarkan konsep daur hidup tersebut, dapat dijabarkan prinsip dari manufaktur berkelanjutan Lowell Centre for Sustainable Production [20] dan
Krajnc dan Glavič [21]: (1) Produk dan kemasan didesain supaya aman selama siklus hidup produk tersebut. (2) Pelayanan diatur supaya dapat memuaskan kebutuhan manusia dan menjunjung keadilan. (3) Limbah dan sampah produksi dikurangi, dihilangkan, atau didaur ulang. (4) Bahan kimia dan bahan lain yang berbahaya untuk kesehatan dihilangkan. (5) Energi dan material dilestarikan, dan energi dan material yang digunakan adalah yang paling tepat. (6) Tempat kerja dan teknologi didesain untuk meminimalisir atau menghilangkan bahaya kimia, bahaya ergonomi, dan bahaya fisik. (7) Pekerjaan diatur untuk mempertahankan dan meningkatkan efisiensi dan kreatifitas pekerja. (8) Keamanan dan keberlangsungan semua pekerja adalah prioritas, seperti juga perkembangan terusmenerus dari bakat dan kapasitas pekerja. (9) Masyarakat sekitar tempat kerja dihormati dan diuntungkan secara ekonomi, sosial, budaya, dan fisik. (10) Keberlangsungan ekonomi jangka panjang perusahaan ditingkatkan.

Di Indonesia isu keberlanjutan sudah mulai berkembang namun banyak kendala yang dihadapi oleh industri, yang juga teridentifikasi di negaranegara lain khususnya di negara berkembang atau di industri berukuran kecil dan menegah (Small Medium Enterprise /SME). Secara umum, hambatan yang dihadapi dalam penerapan manufaktur berkelanjutan adalah hambatan ekonomi, hambatan teknologi, dan hambatan managerial (Dornfeld et al. [15]). Secara ekonomis, tuntutan pengurangan dampak negatif lingkungan dapat mempengaruhi kinerja perusahaan. Walaupun kegiatan pencegahan polusi, product stewardship, dan pengontrolan emisi dapat mengurangi biaya pengelolaan limbah dan konsumsi material, namun investasi yang tinggi dan payback period yang panjang menyebabkan keragu-raguan industri untuk melaksanakan manufaktur berkelanjutan (Khalili et al. [12]). Keterbatasan teknologi dalam pengukuran energi, emisi dan dampak lingkungan secara sistematis juga menjadi hambatan (van Hoof dan Lyon [10]).

Kendala lainnya terkait dengan masalah keterbatasan sumber daya manusia (van Hoof dan Lyon [10], Khalili et al. [12]). van Hoof dan Lyon [10] 
menemukan pada SME hambatan berasal dari kurangnya SDM, kurangnya pengetahuan dan adanya persepsi bahwa mereka tidak menyebabkan dampak lingkungan. Selain itu, pada SME perusahaan seringkali mempunyai sistem dan kemampuan manajerial profesional yang terbatas. Proses pengambilan keputusan yang terpusat pada pemilik, pekerja dengan kemampuan yang terbatas, karyawan tidak dilibatkan dalam pengambilan keputusan, lemahnya pendataan dalam perusahaan, tidak adanya sistem monitoring dalam perusahaan dan keadaan keuangan yang tidak stabil merupakan hambatanhambatan dalam pelaksanaan keberlanjutan (Khalili et al. [12]). Dalam setiap aspek keberlanjutan, komitmen manajemen (top management) merupakan hal yang terpenting (Schneider dan Wallenburg [23]).

\section{Indikator Manufaktur Berkelanjutan dan Per- spektif Industri}

Agar manufaktur berkelanjutan dapat dilakukan oleh perusahaan manufaktur berskala besar maupun kecil, diperlukan adanya suatu indikator. Terdapat berbagai jenis indikator yang digunakan untuk mengukur keberlanjutan suatu organisasi. Tabel 1 menjabarkan beberapa indikator yang banyak digunakan. National Institute of Standards and Technology (NIST) mengumpulkan indikator manufaktur berkelanjutan dari berbagai sumber yang telah ada dan membaginya ke dalam 5 kategori, yaitu 3 kategori utama dan 2 kategori tambahan. Ketiga kategori utamanya adalah lingkungan, ekonomi dan sosial, sementara kedua kategori tambahannya adalah teknologi dan manajemen kinerja (N. US Department of Commerce [24]).

Indikator yang paling banyak digunakan secara global adalah indikator dalam laporan keberlanjutan global reporting initiative. Lebih dari 18.000 laporan keberlanjutan telah diterbitkan sejak tahun 1999 sampai dengan tahun 2014. Kegiatan pelaporan kegiatan keberlanjutan atau sustainability reporting sudah mulai dilakukan di Indonesia sejak tahun 2005 namun baru mulai terlihat signifikan pada tahun 2012, terutama untuk di wilayah Asia Tenggara. Hal ini berkenaan dengan diharuskannya negara-negara untuk menerbitkan laporan berkelanjutan oleh bursa efek (tahun 2007 untuk Malaysia, tahun 2013 untuk Thailand, tahun 2009 untuk Tiongkok). Laporan berkelanjutan difokuskan untuk perusahan-perusahaan yang terdaftar di dalam bursa efek, perusahaan-perusahaan ini masuk dalam kategori perusahaan besar.

Gambar 3 menunjukkan jumlah laporan keberlanjutan yang diterbitkan di negara-negara Asia Tenggara dibandingkan dengan Jerman, Australia dan Amerika Serikat per tahun sejak 1999 sampai 2014. Amerika Serikat merupakan negara dengan jumlah laporan terbanyak di dunia (2066 laporan), diikuti oleh Spanyol (1339 laporan) dan Afrika Selatan
(1282 laporan). Untuk wilayah Asia Tenggara, Thailand masih yang terbanyak, diikuti oleh Singapura dan Indonesia. Hal ini karena kesadaran lingkungan dan penelitian di bidang keberlanjutan di Thailand yang sudah lebih berkembang (Gambar 4). Gambar 4 menunjukkan jumlah artikel jurnal dalam bidang Life Cycle Assessment yang diterbitkan di negara-negara ASEAN berdasarkan hasil penelusuran pada web of sciences dan Thomson Reuters yang dilakukan oleh Indonesian Life Cycle Assessment Network (ILCAN) sampai dengan tahun 2015 (WolCARI2015 [25]). Seperti telah disebutkan sebelumnya, keberlanjutan suatu proses harus dilakukan untuk seluruh daur hidupnya. Oleh karena itu, Life Cycle Assessment menjadi salah satu tolok ukur untuk keberlanjutan. Pada gambar tersebut terlihat bahwa penelitian di Thailand jauh melebihi Malaysia, Singapura dan Indonesia. Hal ini menjelaskan keterkaitannya dengan jumlah laporan keberlanjutan yang dihasilkan (Gambar 3).

Tabel 1. Indikator keberlanjutan

\begin{tabular}{|c|c|c|}
\hline No & Set indikator & Komponen \\
\hline 1 & Global Report Initiative (GRI) & 70 indikator \\
\hline 2 & $\begin{array}{l}\text { Dow Jones Sustainability Index } \\
\text { (DJSI) }\end{array}$ & 12 kriteria \\
\hline 3 & $\begin{array}{l}2005 \text { Enviromental Sustainability } \\
\text { Indicators }\end{array}$ & 76 blok \\
\hline 4 & $\begin{array}{l}2006 \text { Environment Performance } \\
\text { Indicators }\end{array}$ & 19 indikator \\
\hline 5 & $\begin{array}{l}\text { United Nations Committee on } \\
\text { Sustainable Development Indicators }\end{array}$ & 50 indikator \\
\hline 6 & OECD Core Indicators & 46 indikator \\
\hline 7 & Indicator Database & 409 indikator \\
\hline 8 & For Product Sustainability Index & 8 indikator \\
\hline 9 & $\begin{array}{l}\text { GM Metrics for Sustainable } \\
\text { Manufacturing }\end{array}$ & 46 metrik \\
\hline 10 & $\begin{array}{l}\text { ISO } 14031 \text { enviromental performance } \\
\text { evaluation }\end{array}$ & $\begin{array}{l}155 \text { contoh } \\
\text { indikator }\end{array}$ \\
\hline & $\begin{array}{l}\text { Wal-mart Sustainability Product } \\
\text { Index }\end{array}$ & 15 pertanyaan \\
\hline & $\begin{array}{l}\text { Enviromental Indicators for } \\
\text { European Union }\end{array}$ & 60 indikator \\
\hline & Eco-Indicators 1999 & 3 faktor utama \\
\hline 14 & Science and Technology Indicators & 13 indikator \\
\hline
\end{tabular}

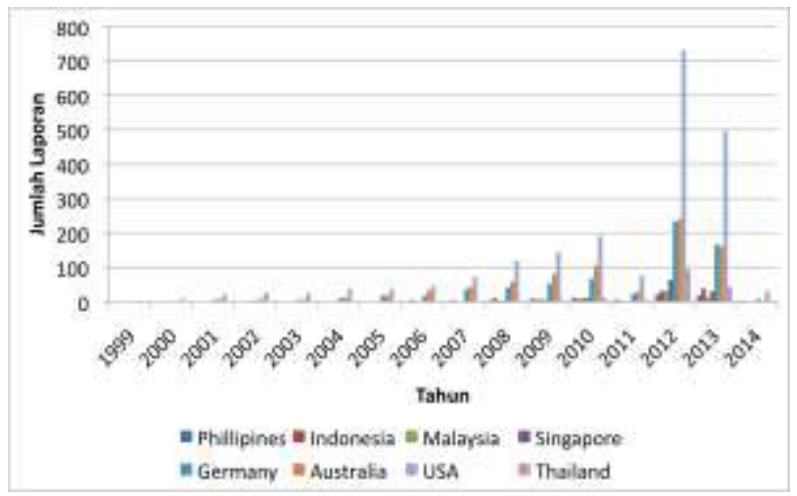

Gambar 3. Jumlah laporan keberlanjutan pada Negara negara di Asia Tenggara dibandingkan dengan USA, Australia dan Jerman. 


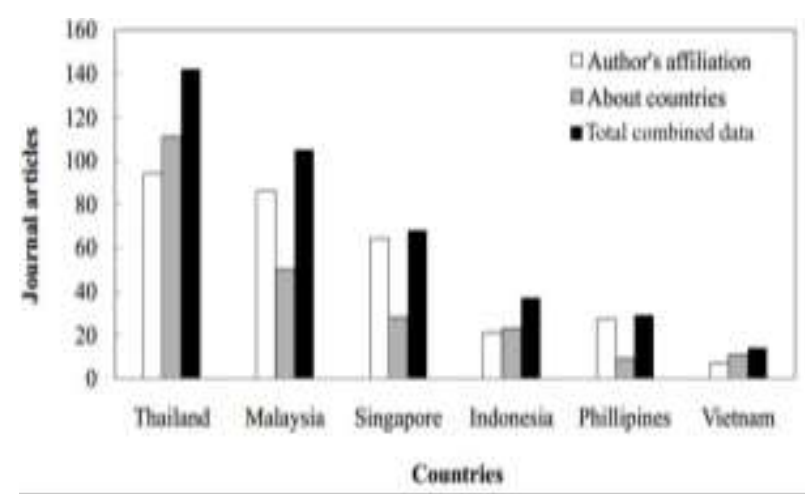

Gambar 4 Jumlah artikel jurnal di bidang Life Cycle Asssement yang diterbitkan dalam bidang berdasarkan negara afiliasi dan asal penulis sampai dengan Februari 2015 (WoLCARI2015 [25]).

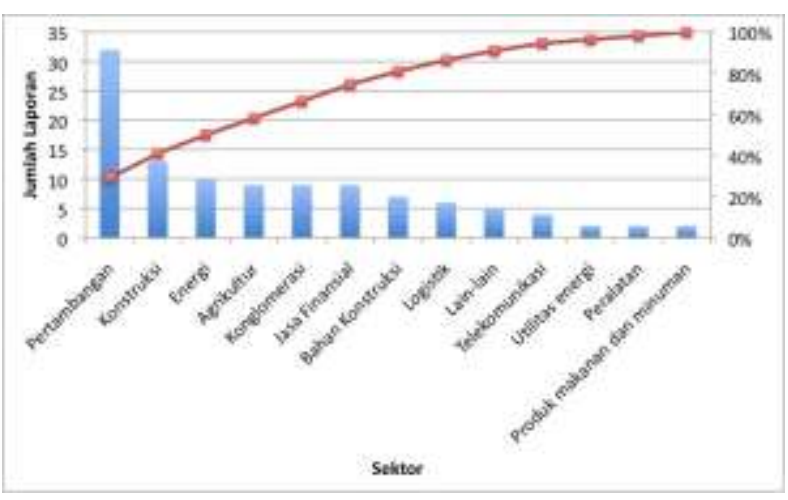

Gambar 5. Sektor industri yang menerbitkan laporan keberlanjutan di Indonesia.

Sektor industri yang paling banyak menerbitkan laporan keberlanjutannya adalah sektor pertambangan (mining), konstruksi, energi, agrikultur, konglomerasi, bisnis keuangan dan bahan konstruksi (Gambar 4). Jika dilihat dari mayoritas sektor yang melaporkan kegiatan keberlanjutannya, sektorsektor ini memang yang paling banyak dituntut untuk melaporkan dampak lingkungan dari kegiatannya. Selain itu, pemangku kepentingan yang beragam pada sektor-sektor ini juga menyebabkan tingginya jumlah laporan keberlanjutan pada sektor-sektor tersebut. Pemangku kepentingan ini misalnya adalah pembeli dari manca negara yang menuntut keberlanjutan dari produk yang dibelinya dan juga lembaga swadaya masyarakat yang memperhatikan keadaan lingkungan dan sosial. Adapun industri manufaktur yang di luar dari konglomerasi belum terlihat aktivitasnya untuk penerbitan laporan berkelanjutan. Pada tahun 2013 berdasarkan laporan dari seluruh dunia, Global Reporting Initiatives melaporkan industri manufaktur yang masuk dalam 10 sektor utama antara lain industri tekstil, telekomunikasi, makanan minuman, dan peralatan. Namun tidak ada perusahaan Indonesia yang bergerak dalam sektor-sektor tersebut yang menerbitkan laporan keberlanjutannya (Global Reporting [26]).
Kegiatan yang dilaporkan oleh industri di Indonesia dalam Sustainability Reporting atau laporan keberlanjutan kebanyakan dalam aspek ekonomi dalam upaya meningkatkan pendapatan, dan dalam aspek sosial dalam rangka menjaga kesehatan karyawan, meningkatkan kesejahteraan pegawai, memiliki keadilan terhadap pegawai, menjunjung tinggi HAM, meningkatkan upaya pengembangan karyawan dan meningkatkan upaya pengembangan masyarakat. Untuk perusahaan besar, konsistensi pendapatan dan peningkatan pendapatan merupakan hal yang menjadi target utama. Selain itu, karena mereka juga mempunyai tanggung jawab untuk melaporkan keadaan keuangannya kepada para pemegang saham, aspek ekonomi ini menjadi hal yang paling banyak dilaporkan untuk menunjukkan kesehatan dan kelangsungan perusahaan.

Secara terpisah, indikator-indikator tersebut dihadapkan kepada SME di sekitar Jabodetabek. Hambatan terbesar dalam pengukuran adalah keterbatasan data. Sebagai contoh, pada aspek lingkungan untuk mengurangi limbah cair yang dihasilkan digunakan indikator jumlah limbah cair yang dihasilkan. Data tersebut tidak tersedia pada perusahaan-perusahaan $S M E$ yang dijadikan sebagai studi kasus dalam penelitian ini. Untuk itu dibentuklah suatu pengukuran yang sederhana berdasarkan klasifikasi NIST untuk mengetahui seberapa siapnya industri di Indonesia untuk menghadapi manufaktur berkelanjutan yang disebut sebagai Indikator Manufaktur Berkelanjutan yang disederhanakan (Simplified Sustainable Manufacturing Indicator).

Penyederhanaan indikator dilakukan dengan menggabungkan beberapa indikator. Misalnya pada aspek lingkungan sub-aspek emisi, indikator "jumlah limbah cair yang dihasilkan", "proporsi limbah cair yang berbahaya" dan "total limbah yang dihasilkan" digabungkan menjadi "pengurangan limbah yang dihasilkan". Selain itu, pengukurannya juga diubah dari nilai kuantitatif dalam NIST menjadi derajat kesulitan implementasi, keberadaan data dan tingkat penerapan dalam Indikator Manufaktur Berkelanjutan yang Disederhanakan (IMBYD).

Lima belas industri manufaktur berukuran kecil dan menengah di sekitar Jabodetabek dipilih secara acak (non-purpossive sampling) untuk dijadikan sebagai studi kasus. Dilakukan wawancara terstruktur terhadap perwakilan dari industri. Perwakilan yang diwawancara merupakan pemilik atau bagian dari manajemen atas (top management) Berdasarkan studi kasus, hanya sekitar 30\% dari sampel industri yang mengerti tentang konsep keberlanjutan dalam perusahaannya. Berdasarkan 
survey pada sampel, aspek yang paling sulit dilakukan adalah penerapan aspek ekonomi (100\%), diikuti oleh lingkungan dan sosial. Hal ini dikarenakan industri SME masih mempunyai keterbatasan sumber daya, pendapatan yang tidak stabil, dan kesulitan dalam investasi. Hambatan aspek ekonomi ini juga berdampak pada aspek lingkungan dan sosial, dimana perusahaan tidak mempunyai modal untuk membeli mesin yang ramah lingkungan atau dana untuk melaksanakan kegiatan tanggung jawab sosial perusahaan. Aspek lingkungan juga memerlukan pendataan yang baik, namun kegiatan penghematan sumber daya dan energi bisa dimulai dari kegiatan-kegiatan sederhana. Aspek sosial dianggap sebagai aspek yang paling mudah diterapkan karena dapat dimulai dengan kesejahteraan pegawai. Tata kelola perusahaan dapat menjadi kendala jika komitmen yang diberikan oleh manajemen belum terfokus pada keberlanjutan. Teridentifikasi subaspek yang paling sulit dalam aspek sosial adalah yang berkenaan dengan konsumen.

Jadi jika kita bandingkan antara perusahaan besar dengan perusahaan kecil dan menengah dapat disimpulkan bahwa untuk perusahaan besar yang sudah mapan, fokus pelaporan keberlanjutan akan tertuju pada sisi ekonomi untuk menunjukkan keadaan perekonomian mereka kepada para investor dan pemangku kepentingan. Sementara untuk industri kecil dan menengah, keadaan ekonomi yang belum mapan bukanlah penghalang untuk menjadi industri yang berkelanjutan. Strategi-strategi penghematan sumber daya alam dan energi, yang dimulai dengan pendataan penggunaan sumber daya dan energi, dapat digunakan untuk meningkatkan efisiensi proses, yang selanjutnya akan menhasilkan keuntungan ekonomis. Hambatan dari pengembangan aspek lingkungan adalah keterbatasan data. Oleh karena itu, berdasarkan hasil studi kasus, aspek sosial merupakan aspek yang paling mudah untuk diterapkan karena adanya data yang lebih tersedia pada industri kecil dan menengah.

\section{Peran Pemerintah dalam Manufaktur Keber- lanjutan}

Perhatian yang diberikan pemerintah Indonesia pada isu keberlanjutan dapat dilihat dari usahausaha yang telah dilakukan oleh lembaga-lembaga kenegaraan yang terkait dengan isu ini. Lembagalembaga kenegaraan yang memiliki keterkaitan dengan manufaktur berkelanjutan antara lain adalah Kementerian Perindustrian, Kementerian Energi dan Sumber Daya Mineral, Kementerian Lingkungan Hidup, Kementerian Tenaga Kerja dan Transmigrasi, Badan Pengkajian dan Penerapan Teknologi, dan Komite Percepatan dan Perluasan Pembangunan Ekonomi Indonesia.
Beberapa upaya yang dilakukan oleh Kementerian Perindustrian RI antara lain adalah pemberian penghargaan pada kawasan industri dengan kinerja terbaik dalam pengelolaan lingkungan, menjajaki kerjasama dengan pemerintah dan investor asing dalam melakukan pengembangan energi terbarukan di Indonesia, menerbitkan modul e-learning mengenai pengelolaan limbah industri pangan, merilis jurnal-jurnal yang berisi tentang penelitianpenelitian yang membahas mengenai reduksi cemaran industri, teknologi untuk pemanfaatan bahan baku, dan inovasi kemasan produk. Pentingnya proses manufaktur berkelanjutan juga diresmikan dengan adanya UU no. 3 tahun 2013 pasal 77 hingga 83 mengenai industri hijau.

Industri hijau sendiri didefinisikan sebagai industri yang dalam proses produksinya mengutamakan upaya efisiensi dan efektivitas penggunaan sumber daya secara berkelanjutan sehingga mampu menyelaraskan pembangunan industri dengan kelestarian fungsi lingkungan hidup serta dapat memberikan manfaat bagi masyarakat. Dalam mewujudkan industri hijau, pemerintah melakukan perumusan kebijakan, penguatan kapasitas kelembagaan, standardisasi, dan pemberian fasilitas. Penguatan kapasitas kelembagaan sendiri dilakukan dengan penelitian dan pengembangan, pengujian, sertifikasi dan juga promosi. Kementerian Perindustrian Republik Indonesia (Kemenperin) juga sudah mulai melakukan inventarisasi Gas Rumah Kaca pada sektor industri sebagai bagian dari kesadaran manufaktur berkelanjutan (Kementrian Perindustrian Republik Indonesia [27]).

Kementerian Lingkungan Hidup dan Kehutanan (KLHK) menyebutkan visinya untuk berperan dalam pelaksanaan pembangungan berkelanjutan dengan menekankan pada konsep ekonomi hijau. Dalam hubungan langsung dengan manufaktur, KLHK telah menetapkan tanggal 1 Januari 2015 sebagai tanggal jatuh tempo manufaktur dan atau perakitan refrigerasi dan air conditioner (AC) untuk mengalihkan penggunaan hydrochlorofluorocarbon (HCFC) ke teknologi non-HCFC dimana penggunaan HCFC dapat merusak lapisan ozon di atmosfer bumi.

Selain itu KLHK juga mempromosikan produksi hijau di kalangan perusahaan dengan melangsungkan Program Penilaian Peringkat Kinerja Perusahaan (PROPER). Dalam program ini dilakukan penilaian peringkat kinerja perusahaan dalam pengelolaan lingkungan. Materi yang diperhitungkan dalam PROPER sendiri cukup banyak, diantaranya sistem manajemen lingkungan, efisiensi energi, efisiensi air, penurunan emisi, keanekaragaman hayati, penurunan dan pemanfaatan lim- 
bah bahan berbahaya dan beracun (B3), recyclereuse-reduce (3R) limbah padat non-B3, pemberdayaan masyarakat, dan dokumen ringkasan kinerja pengelolaan lingkungan (DRKPL) (Sekretariat PROPER [28])

Peranan Kementerian Energi dan Sumber Daya Mineral Republik Indonesia (ESDM) ditandai dengan dibentuknya sebuah badan bernama "Pusat Penelitian dan Pengembangan Teknologi Ketenagalistrikan, Energi Baru, Terbarukan dan Konservasi Energi” (P3TKEBTKE). Program-program seperti Clean Stove Initiative (CSI) juga diluncurkan dalam upaya mengurangi polutan yang dihasilkan rumah tangga dimana program ini merupakan sebuah program yang bertujuan untuk meningkatkan akses masyarakat pada tungku sehat dan hemat energi (Kementrian ESDM Republik Indonesia [29]).

\section{Peran Akademia dalam Manufaktur Berkelan- jutan}

Dalam mendukung terjadinya manufaktur berkelanjutan di Indonesia peran akademia sudah tidak dipertanyakan lagi. Akademia menjadi ujung tombak penelitian tentang manufaktur berkelanjutan dan edukasi mengenai hal ini kepada masyarakat dan mahasiswa. Tantangan yang dihadapi saat ini adalah bagaimana menerapkan konsep keberlanjutan bukan hanya sebagai topik spesifik namun terintegrasi di seluruh bidang studi. Dengan menghangatnya isu keberlanjutan di industri dan pemerintah, lulusan perguruan tinggi diharapkan untuk dapat siap dari sisi pengetahuan, kemampuan dan juga sikap.

UNESCO telah menetapkan suatu agensi untuk Education for Sustainable Development (ESD). Dalam programnya, ESD mengintegrasikan isu-isu pengembangan berkelanjutan dalam pengajaran dan pembelajaran. Topik-topik kuncinya antara lain perubahan iklim, pengurangan resiko bencana, biodiversiti, pengurangan kemiskinan, dan konsumsi berkelanjutan. Program ini juga bertujuan untuk memotivasi dan memberdayakan anak didik untuk mengubah perilaku menuju pembangunan berkelanjutan. Kompetensi yang ditekankan antara lain cara berpikir kritis, membayangkan keadaan di masa depan dan membuat keputusan secara kolaboratif (UNESCO [30, 31]).

Khalili et al. [12] melakukan survey mengenai integrasi konsep keberlanjutan dalam pendidikan tinggi. Survey dilakukan di Amerika Serikat dan Tiongkok. Hasil survey menyarankan jenis program yang dapat dilakukan pada pendidikan tinggi. Urutan pengembangannya adalah: (1) Memberikan paparan pengetahuan umum mengenai pem- bangunan berkelanjutan. (2) Mengintegrasikan konsep dasar pengembangan berkelanjutan pada setiap mata kuliah. (3) Memajukan penelitian di area pengembangan berkelanjutan. (4) Mengembangkan konsentrasi/minor dalam bidang pengembangan berkelanjutan. (5) Merancang program pasca sarjana dalan bidang keberlanjutan.

Tantangan yang dihadapi saat ini di Indonesia adalah bagaimana menerapkan konsep keberlanjutan bukan hanya sebagai topik spesifik namun terintegrasi di seluruh bidang studi. Hal ini bisa dimulai dari berbagai level pendidikan mulai dari kesadaran lingkungan di tingkat dasar dan menengah, mengintegrasikan konsep dasar dengan konsep pengembangan berkelanjutan di seluruh tingkatan dan bidang studi, pengembangan penelitian ke arah pengembangan berkelanjutan, serta pengembangan program studi khusus di bidang ini. Contohnya dalam bidang perancangan produk, produk yang dirancang harusnya sudah mempertimbangkan dampak lingkungan, ekonomi dan sosial dari keseluruhan daur hidup produk, mulai dari pemilihan material, proses, metode perakitan, distribusi, penggunaan oleh konsumen, dan juga akhir hidup produk. Semakin menghangatnya isu keberlanjutan di industri dan pemerintah, lulusan perguruan tinggi diharapkan untuk dapat siap dari sisi pengetahuan, kemampuan dan juga sikap

\section{Simpulan}

Berdasarkan hasil penelitian dan studi kasus yang dilakukan, tantangan terbesar dalam pelaksanaan manufaktur berkelanjutan atau manajemen keberlanjutan adalah kurangnya kesadaran akan adanya isu keberlanjutan. Dalam suatu organisasi atau perusahaan, kesadaran ini penting karena keterlibatan manajemen dalam implementasi manufaktur berkelanjutan sangatlah penting. Kendala utama dalam penerapannya adalah kurang atau tidak adanya komitmen dari manajemen utama dan keterbatasan data. Pencatatan data belum menjadi kebiasaan dalam perusahaan. Untuk sebagian besar SME, aspek ekonomi menjadi masalah utama karena keterbatasan sumber daya dan pendapatan yang belum stabil.

Peran pemerintah dalam mendorong terjadinya manufaktur berkelanjutan sudah mulai terlihat, walaupun kebanyakan dari program-program tersebut masih bersifat sukarela. Diharapkan turut campur pemerintah untuk lebih mendorong terjadinya keberlanjutan melalui inventarisasi proses dan data dan tindakan yang tegas bagi pelanggar lingkungan dan sosial, misalnya melalui sosialisasi standardisasi lingkungan, pelaksanaan Life Cycle Assessment, pelaporan emisi gas rumah kaca, data 
kegiatan peningkatan kesejateraan karyawan dan lain-lain. Adanya isu keberlanjutan dan pentingnya isu ini bagi kemajuan bangsa menjadi kesempatan bagi akademia untuk mempersiapkan anak didiknya dengan pengetahuan, kemampuan dan perilaku yang mendukung terjadinya manufaktur berkelanjutan.

Penelitian selanjutnya diperlukan eksplorasi yang lebih mendalam mengenai komitmen industri dalam manufaktur berkelanjutan dan hambatan dan tantangan yang mereka alami sehingga dapat diidentifikasi hambatan dan tantangan tersebut berdasarkan jenis industrinya.

\section{Ucapan Terima Kasih}

Kami berterimakasih atas dukungan dari Penelitian Hibah Bersaing dengan surat penugasan dari Universitas Pelita Harapan nomor: 029/LPPMUPH/III/2015 dan penugasan Kopertis 3 No. :108/K3/KM/2015

\section{Daftar Pustaka}

1. US EPA, US Environmental Protection Agency, Sustainable Manufacturing, Sustainable Manufacturing, 2015. Available: http:// www.epa.gov/ sustainablemanufacturing/. Accessed: 17-Aug2015.

2. O'Brien, C., Sustainable Production: A New Paradigm for a New Millennium, International Journal of Production Economic, 60, 1999, pp. 17.

3. Westkämper, E., Alting, and Arndt, Life Cycle Management and Assessment: Approaches and Visions towards Sustainable Manufacturing (keynote paper), CIRP Annual-Manufacture. Technology, 49(2), 2000, pp. 501-526.

4. Rashid, A. S. H., Evans, S. and Longhurst, P., A Comparison of Four Sustainable Manufacturing Strategies, International Journal of Sustainable Engineering, 1(3), 2008, pp. 214-229.

5. Bocken, N. M. P., Short, S. W., Rana, P., and Evans, S., A Literature and Practice Review to Develop Sustainable Business Model Archetypes, Journal of Cleaner Production, 65(2), 2014, pp. 42-56.

6. Reich-Weiser, C., Simon, R., Fleschutz, T., Yuan, C., Vijayaraghavan, A., and Onsrud, H., Metrics for Green Manufacturing, in Green Manufacturing, Dornfeld, D. A., Ed. Springer US, 2013, pp. 49-81

7. Huang, Y., Luo, J., and Xia, B., Application of Cleaner Production as an Important Sustainable Strategy in the Ceramic Tile Plant: A Case Study in Guangzhou, China, Journal of Cleaner Production, 43, 2013, pp. 113-121.
8. Büyükbay, B., Ciliz, N., Goren, G. E., and Mammadov, A., Cleaner Production Application as a Sustainable Production Strategy, in a Turkish Printed Circuit Board Plant, Resources. Conservation and Recycle, 54(10), 2010, pp. 744751.

9. Almeida, C. M. V. B., Bonilla, S. H., Giannetti, B. F., and Huisingh, D., Cleaner Production Initiatives and Challenges for a Sustainable World: An Introduction to This Special Volume, Journal of Cleaner Production, 47(5), 2013, pp. 1-10.

10. van Hoof, B., and Lyon, T. P., Cleaner Production in Small Firms Taking Part in Mexico's Sustainable Supplier Program, Journal of Cleaner Production, 41, 2013, pp. 270-282.

11. Nïnimäki, K., and Hassi, L., Emerging Design Strategies in Sustainable Production and Consumption of Textiles and Clothing, Journal of Cleaner Production, 19(16), 2011, pp. 1876-1883.

12. Khalili, N. R., Duecker, S., Ashton, W., and Chavez, F., From Cleaner Production to Sustainable Development: The Role of Academia, Journal of Cleaner Production, 96(6), 2014, 3043

13. Grutter, J. M., and Egler, H.-P., From Cleaner Production to Sustainable Industrial Production Modes, Journal of Cleaner Production, 12(3), 2004, pp. 249-256.

14. Narayanaswamy V., and Stone, L., From Cleaner Production to Sustainable Production and Consumption in Australia and New Zealand: Achievements, Challenges, and Opportunities, Journal of Cleaner Production, 15,(8-9), 2007, pp. 711-715.

15. Dornfeld, D., Yuan, C., Diaz, N., Zhang, T., and Vijayaraghavan, A., Introduction to Green Manufacturing, in Green Manufacturing, Springer, 2013, pp. 1-23.

16. Guinée, J. B., Handbook on Life Cycle Assessment Operational Guide to the ISO Standards," International Journal of Life Cycle Assessment, 7(5), 2002, pp. 311-313.

17. ISO, International Standard Organisation, ISO 14040: Environmental Management - Life Cycle Assessment - Principles and Framework. 1997.

18. LCI, Life Cycle Initiatives, Social Life Cycle Assessment (S-LCA) | Life Cycle Initiative, 2015. Available: http://www.lifecycleinitiative.org/ starting-life-cycle-thinking/life-cycle-approaches/ social-lcal. Accessed: 19-Aug-2015.

19. UNEP-SETAC Life Cycle Initiative, Guidelines for Social Life Cycle Assessment of Products, U. N. Environ. Programme ISBN, 2009, pp. 978-92.

20. Lowell Centre for Sustainable Production, Lowell Center for Sustainable Production, 2015. Available: ttp://www.sustainableproduction.org/. Accessed: 28-Jun-2015. 
21. Krajnc, D., and Glavič, P., Indicators of Sustainable Production, Clean Technology Environment Policy, 5(3-4), 2003, pp. 279-288.

22. Hanafi, J., Kara, S., and Kaebernick, H., Reverse Logistics Strategies for End-of-Life Products, International Journal of Logistic. Management, 19(3), 2008, pp. 367-388.

23. Schneider, L., and Wallenburg, C. M., Implementing Sustainable Sourcing: Does Purchasing Need to Change? Journal of Purchasing. Supply Management, 18(4), 2012, pp. 243-257.

24. N. US Department of Commerce, NIST Sustainable Manufacturing Indicators Repository (SMIR), 05-Nov-2010. Available: http://www.mel.nist. gov/ msid/SMIR/index.html. Accessed: 17-Aug-2015.

25. WoLCARI 2015, Indonesian Life Cycle Assessment Network. Available: http://www.ilcan.or.id/ events/wolcari-2015/. Accessed: 14-Nov-2015.

26. Global Reporting, Global Reporting Initiative. Available: https://www.globalreporting.org/. Accessed: 14-Nov-2015.

27. Kementerian Perindustrian Republik Indonesia, Inventarisasi Gas Rumah Kaca, 2015. Available: http://grkindustri.kemenperin.go.id/. Accessed: 19-Aug-2015.
28. Sekretariat PROPER Kementerian Lingkungan Hidup dan Kehutanan Republik Indonesia, Program Penilaian Peringkat Kinerja Perusahaan dalam Pengelolaan Lingkungan (PROPER), 2015. Available: http://proper.menlh.go.id/portal/. Accessed: 19-Aug-2015.

29. Kementerian ESDM Republik Indonesia, Pemerintah Luncurkan Kompor Tungku Sehat Kementerian ESDM Republik Indonesia, Agustus 2014. Available: http://ebtke.esdm.go.id/ post/2014/08/14/648/pemerintah.luncurkan.kom por.tungku.sehat. Accessed: 19-Aug-2015.

30. UNESCO, UNESCO | Teaching and Learning for a Sustainable Future, 2010. Available: http://www.unesco.org/education/tlsf/. Accessed: 19-Aug-2015.

31. UNESCO, Education for Sustainable Development | Education | United Nations Educational, Scientific and Cultural Organization, 2015. Available:http://www.unesco.org/new/en/ education/themes/leading-the-internationalagenda/education-for-sustainable-development/. Accessed: 19-Aug-2015. 